\title{
SINTESIS DAN KARAKTERISASI SABUN NATRIUM DARI MINYAK BIJI NYAMPLUNG (Calophyllum inophyllum L.) SERTA UJI AKTIVITAS ANTIBAKTERI TERHADAP Staphilococus aureus
}

\author{
SYNTHESIS AND CHARACTERIZATION OF SODIUM SOAP FROM \\ NYAMPLUNG SEED OIL (Calophyllum inophyllum L.) AND TEST \\ ANTIBACTERIAL ACTIVITY AGAINST Staphilococus aureus
}

\author{
Mochamad Chasani*, Senny Widyaningsih, Adidyan Mubarok \\ Jurusan Kimia FMIPA,Universitas Jenderal Soedirman \\ *email: moch.chasani@gmail.com
}

\begin{abstract}
ABSTRAK
Penelitian ini menggunakan minyak biji nyamplung sebagai bahan dasar sabun antibakteri. Pembuatan sabun dari minyak biji nyamplung dilakukan dengan beberapa tahap yaitu sintesis sabun menggunakan metode saponifikasi dan karakterisasi sabun berdasarkan SNI 06-3532-1994. Untuk mengetahui sifat antibakteri sabun, dilakukan uji aktivitas antibakteri terhadap bakteri Staphylococus aureus. Hasil penelitian menghasilkan sabun yang berwarna kuning dengan berat $13,028 \mathrm{~g}$ dari $10,028 \mathrm{~g}$ minyak biji nyamplung. Karakteristik sabun berdasarkan SNI didapatkan kadar air 25,287\%, jumlah asam lemak $72,177 \%$, alkali bebas $0,082 \%$, lemak yang tidak tersabunkan atau lemak netral $0,834 \%$ dan minyak mineral negatif. Sabun berbahan dasar minyak biji nyamplung memiliki aktivitas antibakteri terhadap Staphylococus aureus dengan diameter zona bening sebesar $14,701 \mathrm{~mm}$.
\end{abstract}

Kata kunci : minyak biji nyamplung, sabun, aktivitas antibakteri, Staphilococus aureus

\section{ABSTRACT}

This research was used nyamplung seed oil as antibacterial soap material. The soap from nyamplung seed oil was performed by saponification reactions, characterization of soap based on SNI 06-3632-1994. The antibacterial activity was tested against bacteria Staphylococus aureus. The result of this research showed that soap had yellow color with weight 13,028 g from 10,028 g nyamplung seed oil. The characteristic of soap based on SNI were water content of $25,287 \%$, fatty acid of $72,177 \%$, free alkali $0,082 \%$, unsoap fatty or free fatty $0,834 \%$, and mineral oil was negative. Soap base on nyamplung seed oil have antibacterial activity against bacteria Staphylococus aureus with diameter of inhibition zone $14,701 \mathrm{~mm}$.

Keyword : nyamplung seed oil, soap, antibacterial activity, Staphilococus aureus

\section{PENDAHULUAN}

Dewasa ini telah banyak dilakukan inovasi-inovasi baru dalam pembuatan sabun sesuai dengan tujuan pemanfaatannya. Jenis-jenis sabun yang banyak dikenal beredar di pasaran khususnya sabun mandi seperti sabun antibakteri, sabun antijamur (Supandi dan Gantini, 2007), sabun kecantikan (Jongko, 2009), dan lain-lain. Semua jenis sabun tersebut berbeda manfaatnya berdasarkan perbedaan formulasi bahan yang 
digunakan dalam pembuatannya. Namun pada umumnya, semua jenis sabun menggunakan bahan dasar yang sama yaitu minyak atau trigliserida. Jenis minyak yang digunakan oleh industri-industri sabun saat ini adalah minyak kelapa dan minyak sawit sebagai bahan utama dan sedikit minyak-minyak lain sebagai bahan tambahan (Afifuddin, 2007).

Semua jenis minyak yang digunakan sebagai bahan dasar pembuatan sabun tersebut termasuk minyak makan (edible oil) yang peman-faatan terbesarnya adalah sebagai minyak goreng. Hal tersebut akan mengakibatkan kompetisi penggunaan bahan baku oleh industri sabun dengan industri minyak goreng sehingga lambat laun salah satu dari industri tersebut akan mengalami kekurangan bahan baku. Beberapa solusi dari masalah tersebut yang dikem-bangkan adalah dengan menambah produksi kelapa dan sawit (sebagai bahan baku). Namun solusi tersebut akan membutuhkan lahan yang cukup besar dan waktu yang lama. Solusi lain yang dapat dilakukan adalah dengan memanfaatkan bahan baku alternatif.

Salah satu tanaman hutan yang mempunyai potensi sebagai bahan baku sabun adalah minyak yang bersumber dari biji Nyamplung (Calophyllum inophyllum L.). Nyamplung (Calo-phyllum inophyllum) di Indonesia tersebar mulai dari Sumatera Barat, Riau, Jambi, Sumatera Selatan, Lampung, Jawa, Kalimanatan Barat, Kalimantan Tengah, Sulawesi, Maluku, hingga Nusa Tenggara Timur dan Papua. Kelebihan nyamplung sebagai bahan baku sabun adalah biji nyamplung memiliki keunggulan ditinjau dari prospek pengembangan dan pemanfaatan lain, antara lain : (1) Tanaman nyamplung tumbuh dan tersebar merata secara alami di Indonesia, regenerasi mudah dan berbuah sepanjang tahun menunjukkan daya survival yang tinggi terhadap lingkungan; (2) Tanaman nyamplung relatif mudah budidayakan.

Biji nyamplung dapat digunakan sebagai obat kudis (Heyne, 1987), hal tersebut menunjukkan bahwa biji nyamplung memiliki aktivitas antiseptik yang dapat digunakan untuk mencegah dan membunuh bakteri. Apabila minyak biji nyamplung dapat digunakan sebagai sabun mandi maka disinyalir sabun tersebut memiliki aktivitas antiseptik dan dapat digunakan sebagai sabun kesehatan.

Pembuatan sabun dari minyak biji nyamplung memiliki tahapan diantaranya adalah isolasi minyak biji nyamplung dengan metode maserasi, minyak hasil isolasi disintesis menjadi sabun menggunakan metode saponifikasi dengan basa $\mathrm{NaOH}$, setelah terbentuk sabun kemudian dikarakterisasi berda-sarkan Standar Nasional Indonesia mengenai sabun. Karakterisasi tersebut diantaranya pengujian kadar air, jumlah asam lemak, jumlah asam lemak bebas dan alkali bebas, uji lemak tak tersabunkan dan lemak netral, uji mineral minyak, dan uji aktivitas antibakteri sabun dan minyak terhadap bakteri staphylococcus aureus. Penelitian ini diharapkan bisa memberikan informasi tentang pembuatan sabun dari minyak biji nyamplung dan karakteristiknya berdasarkan Standar Nasional Indonesia serta aktivitas antibakterinya.

\section{METODE PENELITIAN}

Peralatan yang digunakan pada penelitian ini adalah hotplate stirer, termometer, blender, timbangan analitik, rotary evaporator, seperangkat alat refluks, batang pengaduk, spatula, gelas ukur, Beaker glass, pipet volume, filler, labu ukur, cetakan sabun, kain muslin, labu Erlenmeyer $250 \mathrm{~mL}$, penangas air, oven, cawan Petri, autoklaf, tabung reaksi, crock bor, mikro pipet $50 \mu \mathrm{L}$, spektrofotometri, shaker inkubator, inkubator dan jangka sorong. 
Bahan yang digunakan pada penelitian ini adalah minyak biji nyamplung, $\mathrm{Na}_{2} \mathrm{SO}_{4}$ anhidrat, akuades, nheksana, etanol-eter $(1: 1)$, indikator fenoftalin (pp), Kalium hidroksida $(\mathrm{KOH})$, karbontetraklorida $\left(\mathrm{CCl}_{4}\right)$, pereaksi Hanus (iodin monobromida dalam asam asetat), kalium iodida (KI), akuades, natrium tiosulfat $\left(\mathrm{Na}_{2} \mathrm{~S}_{2} \mathrm{O}_{3}\right)$, larutan kanji, natrium hidroksida $(\mathrm{NaOH})$, pengharum, pewarna makanan, metil jingga, asam klorida $(\mathrm{HCl})$, etanol PA, bakteri Staphylococus aureus, media Nutrient Agar (NA) padat, pepton, yeast, agar kering, glukosa, kapas, kontrol positif (tetrasiklin), kontrol negatif (akuades).

Prosedur kerja penelitian meliputi:

\section{Pembuatan sabun}

Pembuatan sabun dimulai dengan menyiapkan cetakan atau loyang yang sudah dilapisi dengan minyak goreng. Sebanyak 10 g minyak biji nyamplung diaduk dan dipanaskan menggunakan magnet stirrer hingga suhu $60-70{ }^{\circ} \mathrm{C}$, ditambahkan 4,9 mL larutan $\mathrm{NaOH} 30 \%$ dan ditunggu hingga mengental. Larutan hasil sabun dituang ke dalam loyang yang sudah dilapisi minyak dan ditutup dengan kain. Simpan sabun dalam cetakan hingga sabun memadat dan kemudian dikeluarkan dari cetakan (Dalimunthe, 2009)

\section{Karakterisasi sabun}

Terdapat beberapa karakterisasi sabun yang dilakukan dalam penelitian ini, diantaranya adalah uji kadar air, jumlah asam lemak, jumlah asam lemak bebas atau alkali bebas, lemak yang tidak tersabunkan dan lemak netral, dan minyak mineral (Standar Nasional Indonesia, 1994)

\section{Uji aktivitas antibakteri terhadap minyak dan sabun}

\section{Sterilisasi alat}

Sterilisasi dilakukan sebelum peralatan digunakan dengan cara semua peralatan dibungkus menggunakan kertas dan disterilkan dalam autoklaf pada suhu $121^{\circ} \mathrm{C}$ dengan tekanan 15 psi (persquare inci) selama 15 menit, sedangkan alat yang tidak tahan panas disterilkan dengan alkohol $70 \%$.

\section{Penyiapan media}

Media yang digunakan dalam penelitian ini terbagi menjadi tiga jenis, yaitu :

a. Media NA digunakan untuk peremajaan biakan murni. Bahan yang digunakan dalam pembuatan media NA adalah $0,1 \mathrm{~g}$ NA dilarutkan dalam $5 \mathrm{~mL}$ akuades dan dimasukkan ke dalam tabung reaksi serta ditutup lubangnya menggunakan sumbat kapas, kemudian disterilkan menggunakan autoklaf dan dibiarkan memadat pada posisi miring dalam tabung reaksi.

b. Media NB (Nutrient Broth) digunakan untuk produksi bakteri Staphylococus aureus pada media cair. Bahan yang digunakan dalam pembuatan media NB $0,005 \mathrm{~g}$ pepton dan $0,003 \mathrm{~g}$ yeast, kedua bahan tersebut kemudian dilarutkan dalam $10 \mathrm{~mL}$ akuades dan disterilkan menggunakan autoklaf.

c. Media PYG (Pepton Yeast Agar) digunakan untuk media pembiakan bakteri yang ditempatkan pada cawan Petri ukuran kecil dan media ini digunakan pada saat uji aktivitas antibakteri dengan metode difusi. Bahan yang digunakan adalah glukosa, agar kering, pepton dan yeast. Penentuan banyaknya bahan yang digunakan dilihat dari jumlah cawan yang digunakan sebagai tempat penyimpanan sampel. Dalam penelitian uji aktivitas antibakteri terdapat 7 variasi dan masing masing variasi dilakukan perlakuan sebanyak triplo, maka dibutuhkan 21 cawan dan masing masing cawan Petri diisi dengan $5 \mathrm{~mL}$ media PYG, jadi banyaknya PYG yang dibutuhkan sebanyak $105 \mathrm{~mL}$. dari banyaknya PYG yang dibutuhkan, dapat dihitung bahan yang perlu disiapkan, diantaranya glukosa sebanyak 2,1 g, agar-agar kering sebanyak 
$2,1 \mathrm{~g}$, pepton sebanyak $1,05 \mathrm{~g}$ dan yeast sebanyak $1,05 \mathrm{~g}$.

Setelah bahan-bahan ditimbang, kemudian dilarutkan dalam $105 \mathrm{~mL}$ akuades dan disterilkan menggunakan autoklaf selama 15 menit. PYG yang sudah steril kemudian diambil sebanyak $5 \mathrm{~mL}$ dan dituangkan pada masing-masing cawan Petri kecil sebanyak 21 buah, setelah itu dibiarkan sampai memadat.

\section{Peremajaan biakan murni}

Biakan murni diremajakan menggunakan media NA yang sudah memadat dengan posisi miring, bakteri Staphylocucus aureus murni diambil sebanyak 1 ose dan di pindahkan ke dalam media NA yang sudah memadat secara aseptis dengan cara menggoreskan biakan murni pada permukaan media NA, kemudian tabung reaksi ditutup dengan sumbat kapas dan diinkubasi selama 24 jama pada suhu $37^{\circ} \mathrm{C}$ (Lay, 1994).

\section{Pembuatan biakan aktif}

Pembuatan biakan aktif dilakukan dengan menyiapkan media NB terlebih dahulu, kemudian diambil bakteri Staphylococus aureus dari media NA sebelumnya sebanyak 1 ose dan dimasukkan ke dalam media NB. Setelah bakteri masuk ke dalam media NB kemudian diaduk menggunakan shaker inkobator pada suhu $37{ }^{\circ} \mathrm{C}$ selama 24 jam (Bintang, 1993).

\section{Uji aktivitas antibakteri}

Uji aktivitas antibakteri dilakukan dengan cara dituangkan sebanyak $5 \mathrm{~mL}$ media Pepton Yeast Agar (PYG) pada suhu $\pm 40{ }^{\circ} \mathrm{C}$ ke dalam cawan Petri steril. Selanjutnya didiamkan pada suhu kamar sampai media agar memadat. Sejumlah biakan bakteri dalam media cair Nutrient Broth (NB) diambil dan disebarkan di dalam media Pepton Yeast Agar (PYG). Volume bakteri yang diambil berdasarkan hasil absorbansinya pada panjang gelombang $\quad 600 \mathrm{~nm}$. Jika nilai absorbansinya kurang atau sama dengan 0,5 maka diambil $100 \mu \mathrm{L}$ biakan bakteri, sedangkan jika 0,6-1,0 diambil 50 $\mu \mathrm{L}$. Hasil absorbansi dari biakan bakteri pada media NB adalah sebesar 1,49, sehingga volume NB yang diambil adalah sebanyak $50 \mu \mathrm{L}$. Suspensi bakteri uji pada media Pepton Yeast Agar (PYG) distreak secara spread plate dengan menggunakan drugalsky, kemudian didiamkan hingga kering selama 15 menit pada suhu kamar. Setelah kering, agar dilubangi dengan diameter $\pm 8 \mathrm{~mm}$ menggunakan crock bor.

Sampel dan kontrol kemudian diambil sebanyak $50 \mu \mathrm{L}$ dan dituang ke dalam masing-masing lubang tersebut dan diinkubasi selama 24 jam pada suhu $37{ }^{\circ} \mathrm{C}$. Sampel yang diujikan adalah sampel minyak dan sabun, sedangkan kontrol yang digunakan adalah kontrol positif (tetrasiklin) dan kontrol negatif (akuades). Sabun dilarutkan dalam pelarut akuades yang memiliki konsentrasi $10 \% \quad(\mathrm{~b} / \mathrm{v})$. Setelah itu, dilihat dan diukur diameter zona bening yang terbentuk menggunakan jangka sorong (Bintang, 1993).

\section{HASIL DAN PEMBAHASAN}

Produk sabun yang terbentuk berupa padatan berwarna kuning (tanpa penambahan pewarna). Warna kuning tersebut sesuai dengan warna minyak biji nyamplung yang digunakan sebagai bahan baku. Sebanyak 10,028 g minyak nyamplung dan $4,9 \mathrm{~mL} \mathrm{NaOH}$ dapat menghasilkan sabun sebanyak 13,652 g. Hasil ini dipengaruhi oleh banyaknya trigliserida yang bereaksi dengan $\mathrm{NaOH}$ (Hadi, 2011). Sabun yang dihasilkan dapat dilihat pada Gambar 1. 


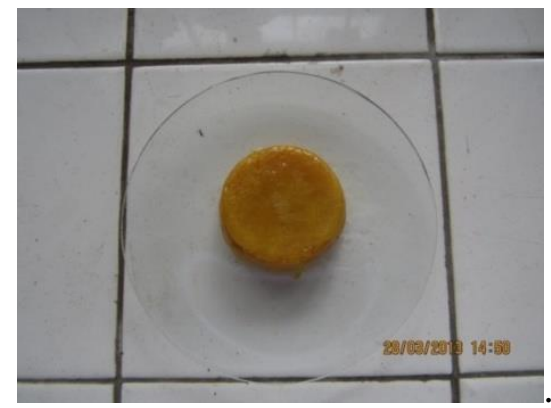

Gambar 1. Sabun natrium dari minyak biji nyamplung

Hasil uji kadar air sabun didapatkan kadar air sebesar 25,287\%. Nilai tersebut menunjukkan jumlah kadar air cukup banyak dan tidak memenuhi standar Standar Nasional Indonesia ( SNI). Hal ini dikarenakan minyak yang digunakan dalam pembuatan sabun masih memiliki kandungan air, setelah minyak diuji kadar air dengan cara dioven sampai berat konstan didapatkan kadar air yang terkandung dalam minyak sebesar $16,605 \%$, kadar air di dalam minyak dimungkinkan mempengaruhi kadar air pada sabun. $\mathrm{NaOH}$ yang digunakan juga berpengaruh terhadap kadar air pada sabun karena konsentrasi $\mathrm{NaOH}$ sebesar $30 \%$ dan masih mengandung cukup banyak air. Banyaknya air yang terkandung dalam sabun akan berpengaruh terhadap kelarutan sabun. Semakin banyak air yang terkandung dalam sabun maka sabun akan semakin mudah menyusut pada saat digunakan.

Hasil uji jumlah asam lemak didapatkan jumlah asam lemak sabun sebesar 72,177\% (b/b). Hasil menunjukkan bahwa kandungan asam lemak sudah memenuhi syarat mutu sabun menurut SNI (1994) dimana kadar jumlah asam lemak harus lebih dari $70 \%$.

Menurut SNI tahun 1994, kadar alkali bebas untuk sabun natrium maksimal $0,1 \%$. Hasilnya adalah sabun dihasilkan warna merah ketika ditambahkan indikator fenolftalin, hal ini menunjukkan bahwa sabun memiliki kelebihan alkali dalam sabun. Nilai alkali bebas yang didapatkan sebesar 0,082\%. Hasil ini menunjukkan bahwa kandungan alkali bebas sangat kecil dalam sabun dan memenuhi syarat mutu sabun menurut SNI.

Kehadiran lemak yang tidak tersabunkan akan menurunkan efektifitas sabun dalam membersihkan kotoran karena sabun tersebut akan mengikat lemak dari dalam sabun itu sendiri, oleh karena itu banyaknya lemak yang tidak tersabunkan atau lemak netral harus lebih kecil dari $2,5 \%$. Hasil yang didapatkan adalah banyaknya lemak yang tak tersabunkan dan lemak netral sebesar $0,834 \%$. Hasil tersebut memenuhi syarat sabun berdasarkan SNI .

Minyak mineral merupakan minyak yang tidak dapat disabunkan karena tidak memiliki gugus ester, sehingga meskipun sudah disabunkan dengan $\mathrm{KOH}$ berlebih akan tetap sebagai minyak, jika ditambahkan air, maka akan terjadi emulsi antara air dengan minyak yang ditandai dengan adanya kekeruhan. Uji minyak mineral dilakukan dengan titrasi lemak netral dengan air, lemak didapatkan dari percobaan uji jumlah asam lemak, pelarut yang digunakan adalah $\mathrm{KOH}$ alkoholis. Hasilnya adalah larutan sabun tetap bening dan berwarna kuning tanpa adanya kekeruhan, hasil ini menunjukkan bahwa kandungan minyak mineral di dalam sabun sangat kecil dan dapat dinyatakan negatif.

Hasil uji aktivitas anti bakteri sebagaimana ditunjukkan pada pada Gambar 2 dan Gambar 3. 


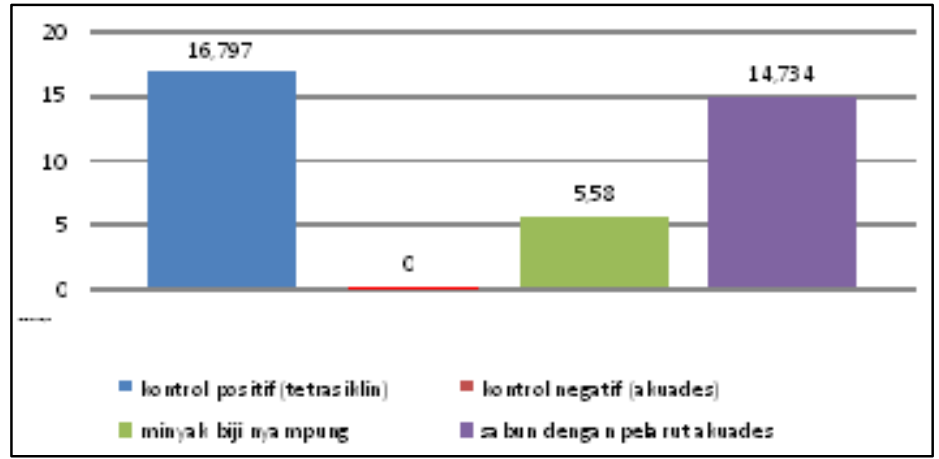

Gambar 2. Grafik hasil uji aktivitas antibakteri sabun nyamplung

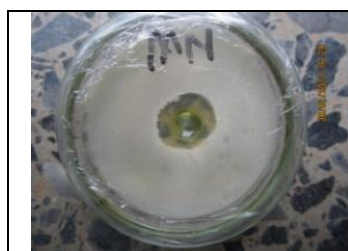

Minyak nyamplung

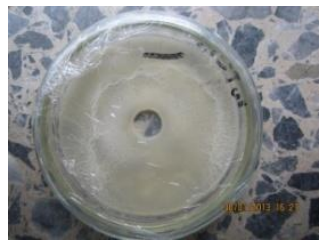

Kontrol negatif (akuades)

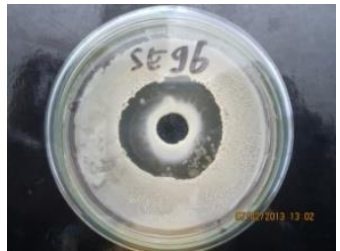

Sabun dengan pelarut etanol 96\%

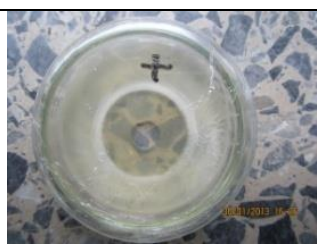

Kontrol positif (tetrasiklin)

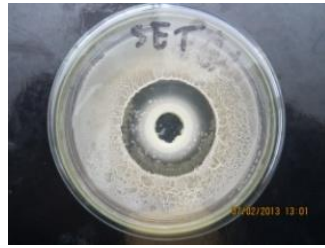

Sabun dengan pelarut etanol PA

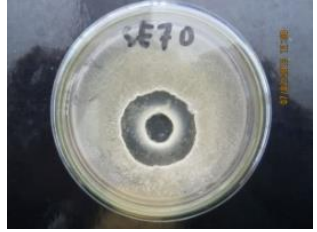

Sabun dengan pelarut etanol $70 \%$

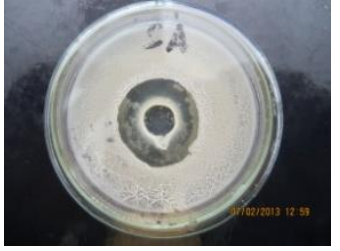

Sabun dengan pelarut akuades

Gambar 3. Gambar hasil uji aktivitas antibakteri

Grafik di atas menunjukkan bahwa kontrol positif (tetrasiklin) menghasilkan diameter zona bening sebesar sebesar 16,797 mm, kontrol negatif (akuades) tidak menghasilkan zona bening, sampel minyak biji nyamplung sebesar 5,58 $\mathrm{mm}$ dan sabun yang dilarutkan dengan akuades sebesar 14,734 mm. Hasil ini menunjukkan bahwa kontrol positif menghasilkan diameter zona bening paling besar, hal ini menunjukkan 
bahwa tetrasiklin memiliki aktivitas antibakteri yang sangat besar. Mekanisme tetrasiklin dalam menghambat pertumbuhan bakteri adalah menghambat sistesis protein bakteri pada ribosomnya. Paling tidak terjadi dua proses dalam masuknya antibiotik ke dalam ribosom bakteri, pertama secara difusi pasif melalui kanal hidrofilik, kedua melalui sistem transport aktif. Setelah antibiotik masuk kemudian berikatan secara reversible dengan ribosom $30 \mathrm{~S}$ dan mencegah ikatan tRNA-amino asil pada kompleks mRNAribosom. Hal tersebut dapat mencegah perpanjangan rantai peptida yang sedang tumbuh dan berakibat terhentinya sintesis protein (Koto, dkk, 2010)

Selanjutnya, diameter yang paling kecil adalah kontrol negatif (akuades). Hasil yang didapatkan ditunjukkan dengan tidak terbentuknya diameter zona bening, hal ini menunjukkan bahwa akuades tidak dapat menghambat pertumbuhan bakteri. Akuades merupakan molekul sederhana yang tidak memiliki gugus aktif dalam menghambat aktivitas bakteri, justru dengan kehadiran air maka bakteri dapat tumbuh.

Minyak nyamplung yang digunakan merupakan hasil pemurnian menggunakan natrium sulfat anhidrat dan minyak biji nyamplung tidak dilarutkan oleh pelarut sehingga dapat dianggap murni. Minyak biji nyamplung memiliki aktivitas antibakteri yang kecil, ditunjukkan dengan rata-rata diameter zona bening yang sangat kecil, yaitu sebesar $5,58 \mathrm{~mm}$. Hasil ini menunjukkan minyak biji minyak biji nyamplung memiliki aktivitas antibaketeri meskipun tidak begitu besar dibandingkan dengan tetrasiklin. Asam lemak pada minyak biji nyamplung diantaranya adalah asam stearat, asam palmitat, asam linolieat dan asam linoleat. Asam lemak tersebut mayoritas diikat dengan gliserol dan hadir dalam bentuk trigliserida. Secara umum aksi penghambatan pertumbuhan bakteri oleh asam-asam organik erat kaitannya dengan kemampuan asam-asam organik dalam menembus membran sel bakteri, lalu mengganggu keseimbangan asambasa, proton dan produksi energi di dalam sel bakteri (Doores, et al., 1983). Meskipun minyak biji nyamplung memiliki aktivitas antibakteri, namun diameter zona bening yang terbentuk kecil, hal ini erat kaitanya dengan ketidakmampuan trigliserida berinteraksi atau menembus membran sel untuk mengacaukan system permeabilitas membrane sel bakteri, karena bentuk trigliserida yang besar dan panjang.

Sabun nyamplung dilarutkan dengan akuades menghasilkan diameter zona bening sebesar 14,734 mm. Hasil yang didapatkan lebih besar dibandingkan dengan diameter zona bening dari minyak biji nyamplung. Hal ini dikarenakan sabun telah berbentuk asam lemak. Bentuk ini lebih kecil dibandingkan dengan bentuk trigliserida sehingga asam lemak lebih mudah berinteraksi dengan membran sel. Hal ini menunjukkan bahwa asam lemak (sisi nonpolar) pada sabun dapat berinteraksi dengan membran sel bakteri, sehingga mengakibatkan sel mengalami lisis dan bakteri tersebut pun tidak dapat betahan hidup.

Perbandingan antara efektifitas sabun dengan kontrol positif (tetrasiklin) memiliki perbedaan aktivitas yang sangat besar. Tetrasiklin memiliki aktivitas antibakteri 100 kali lebih besar dari sabun karena dilihat dari konsentrasi tetrasiklin yaitu $0,1 \%$ dapat membentuk zona bening sebesar 16,797 mm, sedangkan sabun dengan konsentrasi $10 \%$ dan dilarutkan dengan akuades didapatkan diameter zona hambat 14,734 mm. Meskipun perbandingan antara tetrasiklin dengan sabun berbeda tetapi sabun berbasis minyak biji nyamplung memiliki aktivitas antibakteri tanpa adanya zat aditif lainnya.

Sabun yang memiliki aktivitas antibakteri selain berbasis minyak biji 
nyamplung adalah sabun berbasis minyak inti buah ketapang. Menurut Hadi (2011), sabun berbasis minyak inti buah ketapang dengan konsentrasi $10 \%$ dapat menghambat pertumbuhan bakteri Staphylococus aureus dengan diameter zona hambat sebesar $10 \mathrm{~mm}$, sedangkan diameter zona hambat minyak biji nyamplung dengan konsentrasi $10 \%$ sebesar $14,734 \mathrm{~mm}$, kedua sabun tersebut menggunakan pelarut akuades. Jika dibandingkan antara sabun berbasis minyak biji ketapang dan minyak biji nyamplung dengan konsentrasi yang sama, maka sabun berbasis minyak biji nyamplung memiliki aktivitas antibakteri lebih besar dibandingkan dengan sabun berbasis minyak inti buah ketapang.

\section{KESIMPULAN}

Karakteristik sabun dari minyak biji nyamplung berdasarkan Standar Nasional Indonesia didapatkan kadar air $25,287 \%$, jumlah asam lemak $72,177 \%$, alkali bebas $0,082 \%$, lemak yang tidak tersabunkan atau lemak netral $0,834 \%$ dan minyak mineral dianggap negatif. Karakteristik sabun yang sesuai dengan SNI 06-3532-1994 adalah jumlah asam lemak, alkali bebas, lemak tak tersabunkan dan minyak mineral, sedangkan karakteristik sabun yang tidak sesuai dengan SNI 06-3532-1994 adalah kadar air. Sabun berbahan dasar minyak biji nyamplung memiliki aktivitas antibakteri terhadap Staphylococus aureus dengan diameter zona bening dalam pelarut akuades sebesar 14,734 mm.

\section{DAFTAR PUSTAKA}

Afifuddin, S, 2007, Analisis Faktor faktor yang Mempengaruhi Industri $\mathrm{S}$ di Sumatera Utara, Jurnal MIPA Ekonomi, Mei 2007, vol. 2, No. 2.
Bintang, M, 1993, Studi Antimikroba dari Streptococcus latis BCC 229, Disertasi, Program doctor Institut Teknologi Bandung, Bandung.

Dalimunthe A, N., 2009, Pemanfaatan Minyak Goreng Bekas Menjadi Sabun mandi Padat, Tesis, Sekolah Pasca Sarjana / S2, Universitas Sumatera Utara.

Doores, S., In Branen, A. L., and Davidson P.M., 1983, Antimicrobials in Foods, Marcel Dekker, Inc, New york.

Heyne, K, 1987, Tumbuhan Berguna Indonesia, Terjemahan Badan Penelitian dan Pengembangan Hasil Hutan, Koperasi

Hadi, E, L. S, 2011, Pembuatan Sabun Mandi dari Minyak Inti Buah Ketapang (Terminalia cattapa Linn) dengan Metode Saponifikasi, Skripsi, Universitas Mataram, Mataram.

Jongko, 2009, Sabun Kecantikan: Teori dan Praktek Membuat Sabun Beauty di Rumah, Duraposita Chem, Jakarta

Koto, N. P, Mufidah, Pratiwi, S., 2010, Tetrasiklin, Universitas Islam Indonesia, Yogyakarta

Lay, B. W, 1994, Analisis Mikroba di Laboratorium, Raja Grafinda Persadra, Jakarta.

Standar Nasional Indonesia, 1994, Sabun Mandi, Badan Standarisasi Nasional, Jakarta.

Supandi, dan Gantini, S.N., 2007, Formulasi Sabun Transparan Minyak Nilam sebagai Obat Jerawat, Skripsi, Universitas Muhammadiyah, Yogyakarta 